(c) American Dairy Science Association, 2004.

\title{
A Meta-Analysis Examining the Relationship Among Dietary Factors, Dry Matter Intake, and Milk and Milk Protein Yield in Dairy Cows
}

\author{
A. N. Hristov, ${ }^{1}$ W. J. Price, ${ }^{2}$ and B. Shafii ${ }^{2}$ \\ ${ }^{1}$ Department of Animal and Veterinary Science and \\ ${ }^{2}$ Statistical Programs, College of Agricultural and Life Sciences, \\ University of Idaho, Moscow 83844
}

\section{ABSTRACT}

This meta-analysis was undertaken to determine the impact of dietary components on dry matter intake (DMI), milk yield (MY), and milk protein yield (MPY) in Holstein dairy cows. Diets $(\mathrm{n}=846)$ from 256 feeding trials published in Volumes 73 through 83 of the Journal of Dairy Science were evaluated for nutrient composition using 2 diet evaluation models: CPM Dairy (a computer program based on the principles of the Cornell Net Carbohydrate and Protein System) and NRC (2001). Data were analyzed with and without the effect of stage of lactation as a dummy variable $(<100 \mathrm{~d}$ in milk or $\geq 100 \mathrm{~d}$ in milk). A mixed model regression analysis was used to completely investigate the potential relationships among composition variables and DMI, MY, and MPY. Protein and carbohydrate fractions were the main components within the DMI models, and DMI played a dominant role in estimating MY and MPY. Inclusion of stage of lactation substantially improved the MY models but did not affect model fits or residual structure for DMI and MPY.

(Key words: diet composition, dry matter intake, milk yield)

\begin{abstract}
Abbreviation key: $\mathbf{A C}=$ all cows, $\mathbf{B I C}=$ Bayesian Information Criterion, CHO = carbohydrate, DIM 1 = early lactation cows, DIM 2 = mid and late lactation cows, $\mathbf{M Y}=$ milk yield, $\mathbf{M P Y}=$ milk protein yield, $\mathbf{P E}=$ milk protein $\mathrm{N}$ efficiency.
\end{abstract}

\section{INTRODUCTION}

Dry matter intake, milk yield (MY), and milk protein yield (MPY) of dairy cows are interrelated (Moore and Mao, 1990; Rook et al., 1992; Holter et al., 1997; Roseler et al., 1997a; NRC, 2001). A survey of a large data set, including nutritional studies published in Journal of

Received November 17, 2003.

Accepted January 26, 2004.

Corresponding author: A. N. Hristov; e-mail: ahristov@ uidaho.edu.
Dairy Science (Volumes 1 through 82), showed a moderate linear relationship $\left(\mathrm{R}^{2}=0.47\right)$ between DMI and MY (Hristov et al., 2000; Figure 1). Martin and Sauvant (2002) reported a relatively high correlation $(\mathrm{r}=0.52$ to 0.85 ), depending on parity and feed allocation system, between DMI and MY in mid and late lactation cows, emphasizing the importance of DMI as a driving force in milk synthesis. A number of regression models designed to predict DMI based on animal factors have been developed (Blaxter et al., 1966; Yungblut et al., 1981; Kertz et al., 1991; Roseler et al., 1997a) and evaluated (Fuentes-Pila et al., 1996; Roseler et al., 1997b; Pittroff and Kothmann, 2001). Dietary ADF (Yungblut et al., 1981) and NDF and CP (Harlan et al., 1991; Holter et al., 1996, 1997; Rayburn and Fox, 1993) concentrations have been proposed as predictors of DMI. Mertens (1987) indicated the need to integrate animal and feed characteristics into the modeling process to improve intake prediction and understand the relationships among physiological and physical factors regulating DMI in ruminants.

Dietary DM is a multicomponent entity. Diet evaluation and formulation models, using various procedures, have separated dietary CP and energy-yielding substrates into fractions characterized by different rates and extents of ruminal and total tract digestion (Jarrige, 1989; Sniffen et al., 1992; NRC, 2001). In addition to DMI, dietary energy and protein or individual carbohydrate (CHO) and protein fractions may be important factors in controlling MY and MPY in dairy cows. Thus, Rook et al. (1992) identified silage NDF, OM digestibility, and $\mathrm{pH}$ as dietary variables important in predicting MPY and MY. Smoler et al. (1998) suggested individual CHO fractions might be better predictors of MPY than total CHO. The Cornell Net Carbohydrate and Protein System fractionated feed $\mathrm{CHO}$ and proteins through physical or chemical methods (Sniffen et al., 1992). CPM Dairy, a computer program based on the Cornell Net Carbohydrate and Protein System principles, is commonly used in formulating diets for dairy cattle in the US. The seventh edition of the NRC Nutrient Requirements for Dairy Cattle (2001) used the in situ approach to derive information on feed protein degrada- 


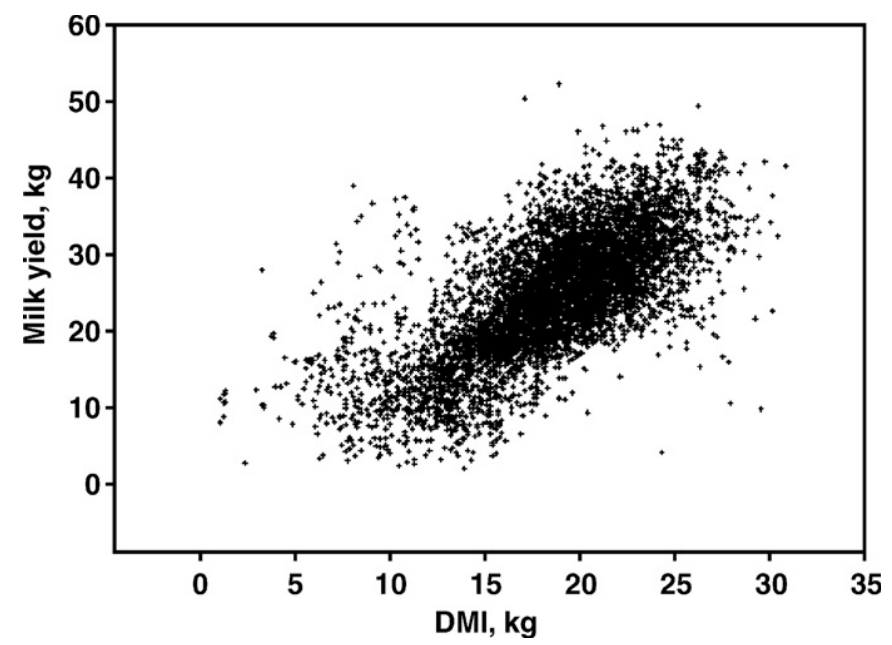

Figure 1. A scatter plot of milk yield vs. DMI in dairy cows $(\mathrm{n}=$ 5814). Data from Hristov et al. (2000).

bility in the rumen; CHO fractions were separated based on chemical analyses (fiber fractions) or by difference (non-fibrous CHO; NFC). Predictions of microbial protein or RUP flows through CPM Dairy (version 1.0) or NRC (1989; the earlier edition of NRC, 2001) have been strongly criticized (Moscardini et al., 1998; Kohn et al., 1998; Santos et al., 1998; Alderman et al., 2001; Bateman et al., 2001; Haig et al., 2002). Compared with microbial protein, however, chemically or physically derived diet composition-related variables are relatively less susceptible to analytical errors and may explain the variability in MY and MPY.

The objective of this study was to determine the impact of dietary components estimated with 2 diet evaluation models on DMI, MY, and MPY in Holstein dairy cows.

\section{MATERIALS AND METHODS}

\section{Input Data}

Diets ( $\mathrm{n}=846$ treatment means) from feeding trials ( $\mathrm{n}=256$ ) conducted in the US and Canada involving Holstein cows and published in Journal of Dairy Science (Volumes 73 through 83)* were evaluated for nutrient composition using 2 diet evaluation models: CPM Dairy (version 1.0; University of Pennsylvania, Kennett Square, PA; Cornell University, Ithaca, NY; and William H. Miner Agricultural Research Institute, Chazy, NY) and NRC (2001). Feeds (and level of processing)

*Contact the corresponding author for a complete list of the references used in this meta-analysis. listed in the publications were matched with feeds from feeding model libraries. The chemical composition of dietary energy and proteinaceous concentrates was not edited. Where available (119 of 256 studies or $46.5 \%$ ), $\mathrm{CP}$ and NDF concentration of forages were modified to reflect actual, published dietary concentrations. Although the output from these nutritional programs may not reflect the actual nutrient composition of each diet, it does provide reasonable estimates. The data were analyzed both as a set (all cows, AC), without regard to DIM, and as cows grouped into 2 categories according to DIM: early lactation cows (DIM $<100,514$ observations; DIM 1) and mid and late lactation cows (DIM $\geq$ 100, 309 observations; DIM 2). The earliest DIM record was 3 , and the latest DIM recorded was 247. Average DIM was published for 575 observations; for 248 observations, DIM was indicated as early, mid, or late. Cows in early lactation were assigned to the DIM 1 group, and cows in mid and late lactation were assigned to the DIM 2 group. For 23 observations, DIM of the cows was not published, and these observations could not be used for structural analysis. Not all variables were present across all observations in the data set. Hence, the number of observations used for regression varied from model to model, depending on the regressor variables contained in each model.

The response variables of interest were DMI, MY, and MPY. The average ( \pm SD) DMI of the cows involved in this study were $22.1 \pm 2.67 \mathrm{~kg} / \mathrm{d}$ with a minimum of 12.2 and a maximum of $29.9 \mathrm{~kg} / \mathrm{d}$. Average MY was $31.9 \pm 5.61 \mathrm{~kg} / \mathrm{d}$ and had a minimum of 20.1 and a maximum of $50.1 \mathrm{~kg} / \mathrm{d}$. Average milk fat and milk protein concentrations were $3.4 \pm 0.38$ and $3.1 \pm 0.21 \%$, respectively. Average milk protein $\mathrm{N}$ efficiency (PE) $[(\mathrm{MPY} \div 6.38) \div \mathrm{N}$ intake] was $24.7 \pm 3.99 \%$, with a minimum and maximum of 13.7 and $39.8 \%$, respectively. Body weight of experimental cows was published in 552 of the observations used in the analysis. Mean $\mathrm{BW}$ was $602 \pm 46.6 \mathrm{~kg}$ (minimum $=476 \mathrm{~kg}$; maximum $=$ $750 \mathrm{~kg}$ ). The dietary variables derived from the feeding programs and considered in the structural analysis are shown in Figure 2. Ratios among protein and energy variables and BW were also considered for potential relationships with the response variables.

\section{Statistical Analyses}

As an initial step, data were inspected for similarity among the nutritional variables. Because most of the data were derived from computational nutritional programs, some variables were essentially numeric derivatives of others and, thus, would be redundant as regressors in any subsequent analysis. This situation could be quickly assessed by calculating simple linear 


\begin{tabular}{ll}
\hline \multicolumn{1}{c}{ CPM Dairy } & \multicolumn{1}{c}{ NRC (2001) } \\
\hline CP & CP \\
RUP & RUP \\
RDP & RDP \\
Soluble protein (SolProt) & Metabolizable protein (MP)) \\
& Metabolizable protein from bacterial protein \\
Metabolizable protein (MP) & (MPBact) \\
Metabolizable protein from bacteria & Microbial CP supply (MCP, g/d) \\
protein (MP Bact) & \\
Metabolizable protein from RUP (MPFeed) & Metabolizable protein from RUP (MPFeed) \\
Protein fraction A (ProtA) & Duodenal AA supply (AA, g/d) \\
Protein fraction B1 (Prot B1) & Digestible AA supply (DigAA, g/d) \\
Protein fraction B2 (ProtB2) & Metabolizable energy (ME, Mcal/kg DM) \\
Metabolizable energy (ME, Mcal/kg DM) & NE (Mcal/kg DM) \\
NE (Mcal/kg DM) & NDF \\
NDF (CHO fractions B2 and C) & Forage NDF (FNDF) \\
Effective NDF (eNDF) & ADF \\
Fermentability of NDF (FermNDF, \%) & Non-fibrous CHO (NFC) \\
Fermentable NDF (FNDF) & Undiscounted TDN (UTDN) \\
Non-structural CHO (NSC) & Discounted TDN (DTDN) \\
CHO fraction A (CHOA) & Fat \\
CHO fraction B1 (CHOB1) & \\
Fermentability of CHOB1 (FermB1, \%) & \\
Fermentable CHOB1 (FCHOB1) & \\
Fermentable CHO (FCHO) & \\
Total CHO (TCHO) & \\
\hline
\end{tabular}

Figure 2. Dietary variables investigated in the structural analysis (\% of DM or as indicated). $\mathrm{CHO}=$ carbohydrate; total $\mathrm{CHO}=\mathrm{CHO}$ fraction $\mathrm{A}+\mathrm{CHO}$ fraction $\mathrm{B} 1+\mathrm{NDF}$.

correlations among the nutritional variables. Pairs of explanatory variables with correlation values $>0.80$ were considered to indicate sufficient redundancy to warrant action. In such cases, only one variable of the pair was selected for further analysis. Preference in these cases was given based on the biological relevance or the reliability of the analytical procedures used to derive the variables. For example, in the CPM-derived data set, the correlation between NDF and effective NDF was 0.85 . Preference here was given to NDF because NDF is the result of a one-step chemical extraction, and effective NDF in CPM Dairy represents complex characteristics of dietary fiber primarily based on physically effective NDF (Mertens, 1997). Thus, the following variables were removed from the structural analysis (see Figure 2 for abbreviations): $\mathrm{ME}$, FermNDF, FNDF, FermB1, FCHOB1, and FCHO (CPM data set) and MCP, MPBact, MPFeed, AA, Di-
gAA, ME, UTDN, discounted TDN (DTDN) (NRC data set).

Multiple linear regression was chosen as a means for investigating the structural relationship among the responses, DMI, MY, and MPY, and the nutritional attributes obtained from CPM and NRC. Because the data used in this meta-analysis were collected from multiple studies conducted over many years, the random effects of each study needed to be accounted for in the modeling process (St-Pierre, 2001). In this case, random effects were incorporated into the estimation procedure using a mixed model framework. The general form of the mixed model is as follows:

$$
\mathbf{Y}=\mathbf{X} \beta+\mathbf{Z} \gamma+\varepsilon
$$

where $\mathrm{Y}$ is the response being modeled, $\mathrm{X}$ is a matrix of the nutritional variables, and $\beta$ is a vector of the 
corresponding regression coefficients. These terms represent the fixed portion of the model and are equivalent to those found in a standard multiple linear regression. The additional components, $\mathbf{Z}$ and $\gamma$, account for the random effects caused by the various studies; $\mathrm{Z}$ represents either all or a portion of the variables present in $\mathrm{X} ; \gamma$ is a vector of their associated coefficients; and $\varepsilon$ is a random error term assumed to be normally distributed with a mean of 0 and a constant variance.

An additional factor for consideration was the precision of each study. To account for this, each regression analysis was weighted by the reciprocal of the squared response standard errors, as reported in each study (StPierre, 2001). Weighting in this manner can improve the overall precision of the regression estimates and ensure homogeneity of variance for the model.

To identify a final model for each response, the backward elimination technique described by Oldick et al. (1999) and Firkins et al. (2001) was used for variable selection. Initially only main (linear) effects were considered in the process because of the large number of variables involved and stability problems created by interaction and quadratic terms. At each stage of elimination, the $P$ value and variance inflation factor of each variable were evaluated as described in Oldick et al. (1999). Variables with $P>0.10$ or a variance inflation factor $>30$ were removed from the model. Once the selection process had identified a reduced model, all possible two-way interactions and quadratic terms derived from the remaining variables were added to the model. The backward elimination procedure was then repeated with the exception that main effects remained in the model, even when nonsignificant, if they were involved in any significant interaction or squared term.

A final factor considered for the modeling process was the effect of DIM. For each model identified by the process outlined previously, a second model was constructed. In these latter models, DIM entered the model as a dummy variable representing the 2 DIM classes: DIM 1 and DIM 2. The DIM variable allowed for estimation of separate coefficients for each variable in the model including intercept terms. These coefficients were then tested for equivalency across DIM classes using single degree of freedom contrasts. When no significant difference was indicated, the dummy variable designation was removed for that model component.

Estimation for all models was carried out using the method of REML, assuming a diagonal variance-covariance (variance component) structure among the regressors. All estimated models were assessed, and a final model for each response was selected based on the Bayesian Information Criterion (BIC), model parsimony, parameter significance, residual analysis, and biological relevance. In addition, mean and linear bi- ases of the selected models were assessed following StPierre (2003). All statistical computations were carried out using the PROC MIXED, PROC REG, and PROC GPLOT procedures of the SAS software system (SAS, 1999).

\section{RESULTS}

The main dietary ingredients and their summary statistics are shown in Table 1. Corn silage, alfalfa silage, and hay were the predominant forage components of the diets. The data set included diets that varied widely in forage-to-concentrate ratio. Corn and barley grains were the main energy concentrates. Solvent-extracted soybean meal was the main protein supplement. Corn gluten meal, fishmeal, blood meal, and meat-bone meal were the sources of RUP. Animal fat and urea were used in 124 and 131 diets, respectively.

Chemical composition of the diets was established using NRC (2001). The diets represented a wide range of CP concentration and ruminal protein degradability. Expressed as a percentage of DM, metabolizable protein concentration of the diets varied from 6.9 to $16.3 \%$. The energy concentration of the diets varied over a relatively narrower range. Neutral detergent fiber and ADF concentrations varied widely among diets. Nonfiber CHO, as specified by NRC (2001), primarily represent the starch component of the diet, but also include soluble fiber, sugars, and organic acids. The diets included in this study had an average NFC concentration of $41.5 \%$ of DM. Phosphorus and particularly Ca concentrations varied significantly among the diets.

Concentration and ruminal fermentability of protein and CHO dietary fractions were estimated using CPM Dairy. The diets surveyed encompassed a significant range of soluble protein and fraction A, B1, and B2 proteins. Protein fraction B3 was not studied because of its low dietary concentration and unlikely effect on ruminal microbial protein synthesis and MY and composition. Similar to the protein fraction, diets varied significantly in $\mathrm{CHO}$ composition.

Efficiency of $\mathrm{N}$ utilization for milk protein $(\mathrm{PE})$ varied considerably among diets. In general, the diets that produced high $\mathrm{PE}$ contained more corn and cereal silages and concentrate and less alfalfa forage. For example, $29 \%$ of the diets with PE $>30 \%$ (77 diets; average $\mathrm{PE}=33 \%$ ) contained alfalfa silage compared with $50 \%$ for all diets in the study. Corn silage was fed with $74 \%$ of the high PE compared with 57\% of all diets; average concentration of corn silage in dietary DM was similar: 35 and $32 \%$, respectively. The high PE diets more often contained corn ( $77 \%$ of the diets compared with $61 \%$ for all diets) and barley grain (29\% vs. $15 \%$, respectively). Average $\mathrm{CP}, \mathrm{NE}_{\mathrm{L}}$, discounted TDN (DTDN), and NFC 
Table 1. Main ingredients and composition of the investigated diets.

\begin{tabular}{|c|c|c|c|c|c|}
\hline Variable & Diets & Average & Minimum & Maximum & SD \\
\hline & (no.) & $-(\%$ or & $\mathrm{DM}$ or as in & cated) - & \\
\hline \multicolumn{6}{|l|}{ Ingredient } \\
\hline Alfalfa silage & 421 & 38 & 5 & 99 & 20.2 \\
\hline Alfalfa hay & 245 & 27 & 4 & 81 & 17.1 \\
\hline Corn silage & 481 & 32 & 4 & 78 & 14.0 \\
\hline Corn grain, ground, dry & 514 & 26 & 1 & 58 & 11.2 \\
\hline High-moisture corn & 147 & 28 & 0.1 & 56 & 10.7 \\
\hline Barley grain, rolled & 125 & 26 & 2 & 62 & 16.0 \\
\hline Dry distiller grains & 119 & 8 & 0.2 & 36 & 7.3 \\
\hline Corn gluten meal & 140 & 3 & 0.3 & 21 & 3.0 \\
\hline Soybean, hulls & 122 & 8 & 0.2 & 34 & 7.0 \\
\hline Soybean meal, solvent ${ }^{1}$ & 640 & 9 & 0.1 & 27 & 5.4 \\
\hline Whole cottonseed & 148 & 10 & 0.5 & 20 & 3.1 \\
\hline Fish meal & 96 & 4 & 0.8 & 19 & 3.2 \\
\hline Blood meal & 126 & 2 & 0.2 & 8.7 & 1.3 \\
\hline Meat-bone meal & 107 & 2 & 0.2 & 8 & 1.6 \\
\hline Molasses & 177 & 2 & 0.2 & 8 & 1.5 \\
\hline Animal fat & 124 & 2 & 0.1 & 8 & 1.5 \\
\hline Urea & 131 & 0.5 & 0.02 & 1.9 & 0.38 \\
\hline \multicolumn{6}{|l|}{ Composition $^{2,3}(\mathrm{n}=846)$} \\
\hline $\mathrm{CP}$ & - & 17.8 & 10.3 & 28.1 & 2.18 \\
\hline $\mathrm{RDP}$ & - & 12.2 & 5.8 & 22.2 & 2.04 \\
\hline RUP & - & 5.6 & 2.8 & 11.6 & 1.22 \\
\hline $\mathrm{MP}$ & - & 10.3 & 6.9 & 16.3 & 1.13 \\
\hline MPBact & - & 5.3 & 3.1 & 6.0 & 0.31 \\
\hline MPFeed & - & 4.5 & 1.9 & 10.2 & 1.05 \\
\hline MCP, g/d & - & 1836 & 902 & 2449 & 232.9 \\
\hline $\mathrm{AA}, \mathrm{g} / \mathrm{d}$ & - & 1252 & 709 & 1760 & 183.9 \\
\hline DigAA, g/d & - & 1007 & 566 & 1459 & 153.0 \\
\hline $\mathrm{ME}, \mathrm{Mcal} / \mathrm{kg} \mathrm{DM}$ & - & 2.54 & 2.14 & 2.96 & 0.096 \\
\hline NEL, Mcal/kg DM & - & 1.61 & 1.32 & 1.96 & 0.074 \\
\hline NDF & - & 30.7 & 18.2 & 53.7 & 4.67 \\
\hline FNDF & - & 22.3 & 5.4 & 53.9 & 5.57 \\
\hline $\mathrm{ADF}$ & - & 20.5 & 11.9 & 35.0 & 3.58 \\
\hline NFC & - & 41.5 & 17.4 & 56.2 & 5.49 \\
\hline DTDN & - & 65.2 & 55.9 & 74.7 & 2.32 \\
\hline Fat & - & 4.0 & 1.9 & 11.7 & 1.41 \\
\hline $\mathrm{Ca}$ & - & 0.61 & 0.20 & 1.70 & 0.269 \\
\hline $\mathrm{P}$ & - & 0.44 & 0.30 & 0.90 & 0.076 \\
\hline \multicolumn{6}{|c|}{ Carbohydrate and protein fractions ${ }^{4}(n=846)$} \\
\hline Soluble protein & - & 6.7 & 3.0 & 15.3 & 1.84 \\
\hline Protein fraction A & - & 4.6 & 1.6 & 11.3 & 1.54 \\
\hline Protein fraction $\mathrm{B} 1$ & - & 2.1 & 0.1 & 4.6 & 0.74 \\
\hline Protein fraction B2 & - & 8.4 & 3.2 & 15.2 & 1.75 \\
\hline CHO fraction A & - & 5.0 & 1.1 & 11.0 & 1.33 \\
\hline $\mathrm{CHO}$ fraction $\mathrm{B} 1$ & - & 37.1 & 15.3 & 51.4 & 5.51 \\
\hline FermB1, \% & - & 75.1 & 61.8 & 87.4 & 6.06 \\
\hline FCHOB1 & - & 27.7 & 12.9 & 41.0 & 3.98 \\
\hline $\mathrm{CHO}$ fractions $\mathrm{B} 2 \mathrm{C}(\mathrm{NDF})$ & - & 30.7 & 18.2 & 53.9 & 4.98 \\
\hline eNDF & - & 7.2 & 2.3 & 26.8 & 2.64 \\
\hline FermNDF, \% & - & 30.2 & 19.9 & 45.3 & 4.85 \\
\hline FNDF & - & 9.4 & 3.6 & 20.6 & 2.56 \\
\hline NSC & - & 42.2 & 24.4 & 55.7 & 5.26 \\
\hline TCHO & - & 72.7 & 60.2 & 81.2 & 2.92 \\
\hline FCHO & - & 41.1 & 27.5 & 53.4 & 3.81 \\
\hline
\end{tabular}

${ }^{1}$ Soybean meal (SBM) was either 44 or $48 \%$ CP (as-is basis). Two diets utilized SBM with 55\% CP (DM basis).

${ }^{2} \mathrm{NRC}(2001)$.

${ }^{3}$ For abbreviations see Figure 2.

${ }^{4}$ CPM Dairy: CPM Dairy is a computer program based on the Cornell Net Carbohydrate and Protein System principles. 
concentration (NRC, 2001) of the high PE diets was $15.8 \%, 1.64 \mathrm{Mcal} / \mathrm{kg}, 66.7 \%$, and $43.4 \%$, respectively, and the average for all diets was $17.8 \%, 1.61 \mathrm{Mcal} /$ $\mathrm{kg}, 65.2 \%$, and $41.5 \%$, respectively. Compared with the average MY per cow from all diets, cows produced more milk in trials where $\mathrm{PE}$ was high: 35.2 vs. $31.9 \mathrm{~kg} / \mathrm{d}$, but milk protein concentration was not different, 3.10 and $3.11 \%$, respectively.

\section{Modeling}

For each response, the backward selection procedure was used to identify a model that had acceptable residual structure, BIC, and parsimony. All final models showed good prediction with residuals that had no discernible trend or pattern. All model residuals were tested for significant mean and linear biases. In all cases, the biases were either non-significant or small relative to the measured standard errors based on analyses similar to St-Pierre (2003). Residual plots for the models with the smallest BIC value (AC or DIM models) are shown in Figures 3 through 5.

DMI models. The final estimated CPM AC-DMI model is given in Table 2 (the reduced DIM model had identical structure to the $\mathrm{AC}$ model). The residual plot is shown in Figure 3. Variables included from the CPM data set were $\mathrm{CP}, \mathrm{NE}_{\mathrm{L}}$, metabolizable protein, metabolizable protein from bacterial protein, and protein fraction B1. The model also contained significant quadratic effects for metabolizable protein from bacterial protein and $\mathrm{NE}_{\mathrm{L}}$. The significant random component for metabolizable protein indicated an interaction of metabolizable protein with the random effect of study.

For NRC, important variables in explaining the variability in DMI were $\mathrm{NE}_{\mathrm{L}}$, metabolizalbe protein, RDP, NDF from forage, ADF, and dietary fat. All variables, except RDP, were highly significant $(P<0.0001)$. Model expansion to include DIM classes did not appreciably affect the model fit and was reduced to the AC model. Fat had a significant interaction with the random effect of study.

MY models. Estimated MY models are shown in Table 3. Dry matter intake, metabolizable protein, metabolizable protein from bacterial protein, and dietary concentration of CHO fraction B1 were significant factors in the CPM-AC model. Metabolizable protein from bacteria had a negative influence in the model. Incorporation of DIM into the CPM model substantially improved model fit as measured by the 140-point decrease in BIC as well as an improved relationship between observed and predicted values and overall residual structure. Dry matter intake showed significantly different coefficients for each DIM class, and the remaining coefficients did not. In both the full and reduced models, DMI
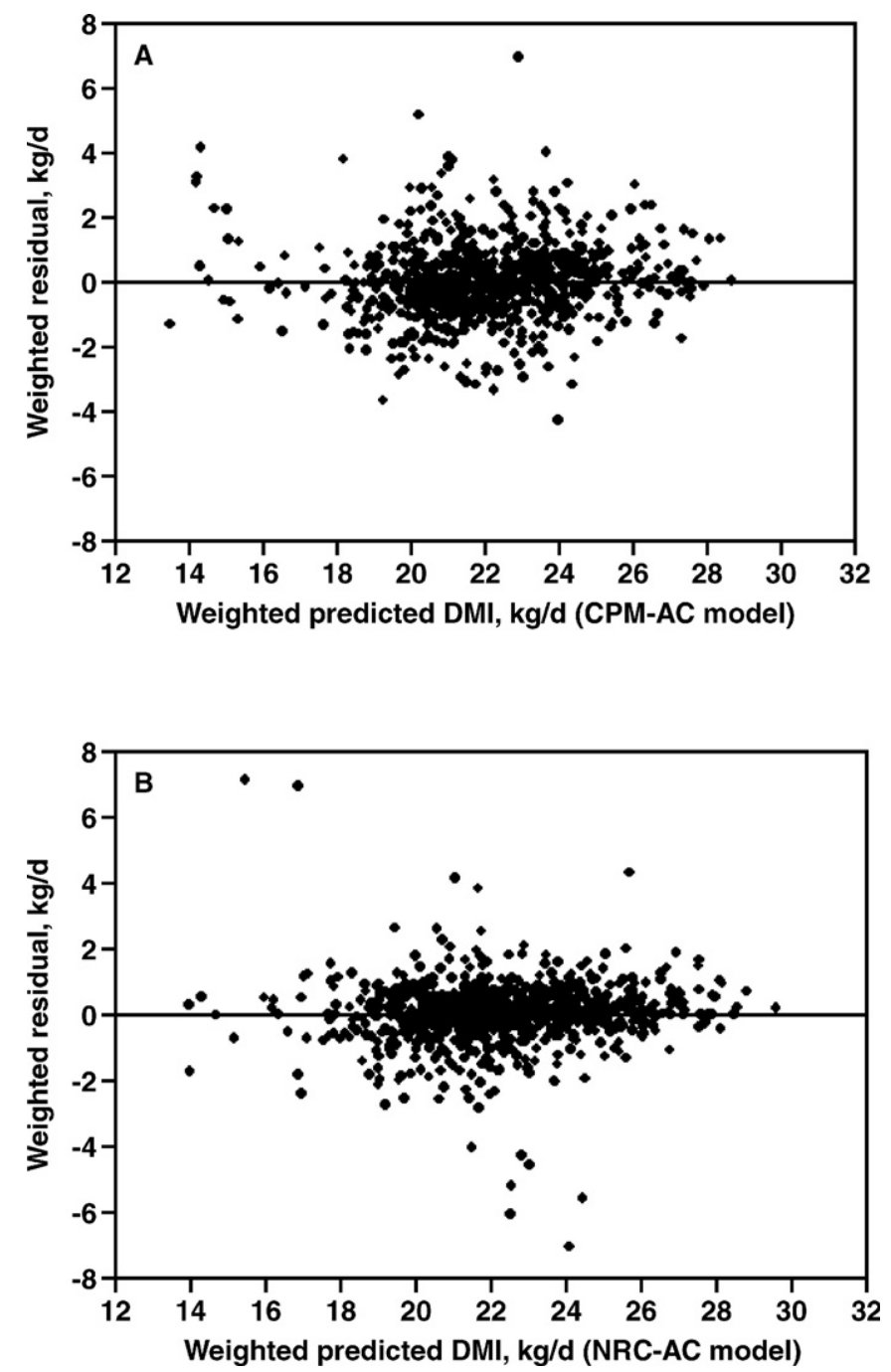

Figure 3. Weighted residuals (weighted observed-weighted predicted) vs. weighted predicted DMI. Panel A: CPM model (a computer program based on the Cornell Net Carbohydrate and Protein System principles), across all lactation stages $(\mathrm{AC}=$ all cows); panel $\mathrm{B}$ : NRC (2001) model, across all lactation stages (AC).

and metabolizable protein had significant interactions with the random effects of study.

The MY model for the NRC data set included DMI, metabolizable protein, and dietary fat as explanatory variables. As was seen in the CPM data set, inclusion of DIM into the modeling process produced a better fit than the AC model with decreased BIC values and an improved relationship between observed and predicted values and residual plot (Figure 4). The significant random component for DMI indicated an interaction of DMI with the random effect of study.

MPY models. Estimated MPY model results are shown in Table 4. Dry matter intake, dietary concentrations of soluble protein, non-structural $\mathrm{CHO}, \mathrm{CHO}$ frac- 

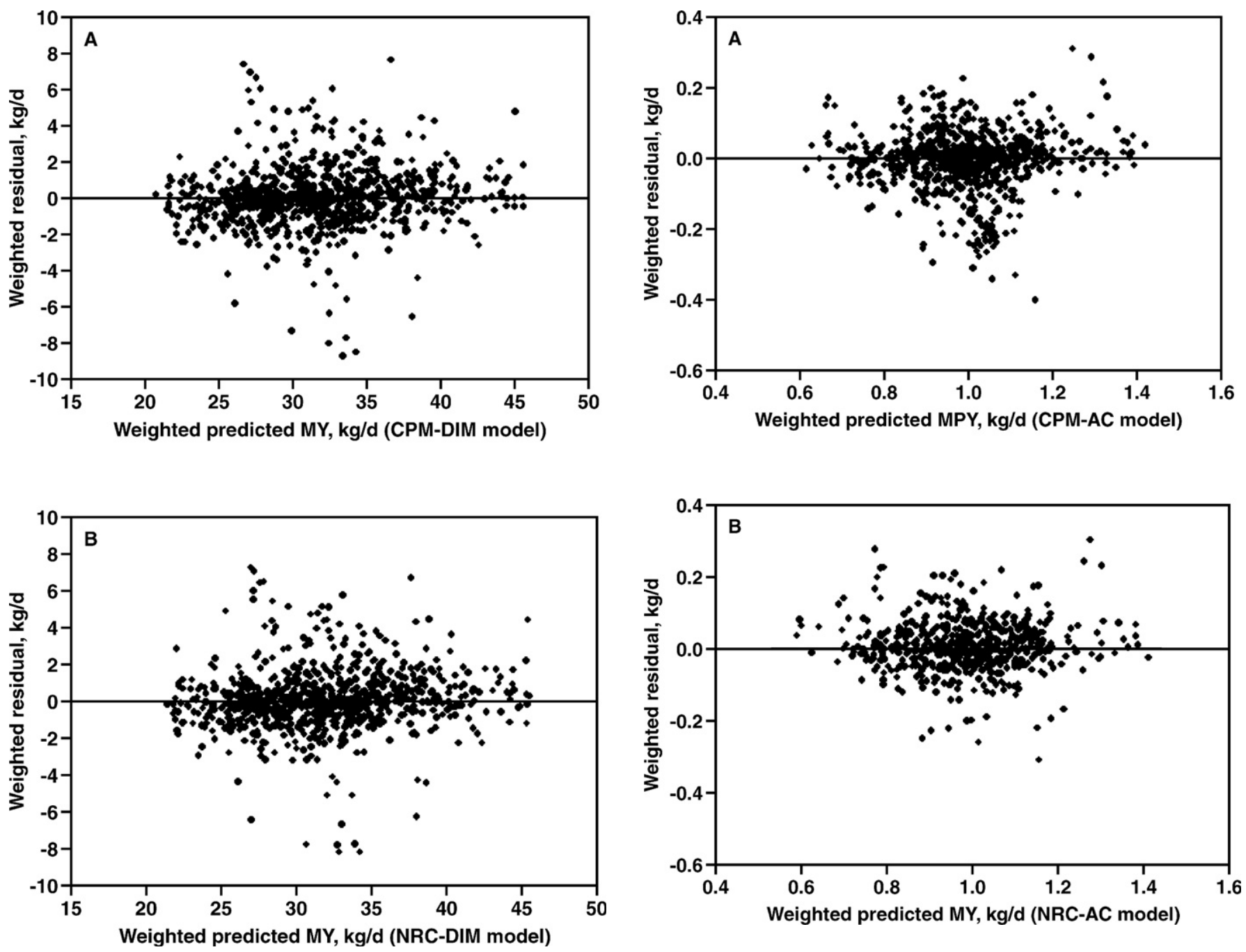

Figure 4. Weighted residuals (weighted observed-weighted predicted) vs. weighted predicted milk yield (MY). Panel A: CPM (a computer program based on the Cornell Net Carbohydrate and Protein System principles)-DMI model; panel B: NRC (2001)-DMI model.

tions $\mathrm{A}$ and $\mathrm{B} 1$, protein fractions $\mathrm{A}$ and $\mathrm{B} 1$, and interactions among DMI and protein fractions and $\mathrm{CHO}$ fraction $\mathrm{B} 1$ and protein faction $\mathrm{B} 1$ were indicated as significant factors in the CPM model. Both $\mathrm{CHO}$ and protein fraction effects had negative coefficients. Inclusion of DIM into the model resulted in separate coefficients for DMI, nonstructural carbohydrates, $\mathrm{CHO}$ fraction $\mathrm{B} 1$, and protein fraction $\mathrm{A}$, but did not improve the model fit or residual structure. The models also contained significant interaction of DMI and soluble protein/protein fraction $\mathrm{A}$ and $\mathrm{CHO}$ fraction $\mathrm{B} 1$ and protein fraction $\mathrm{B} 1$. In both models, DMI and protein fraction A had significant interactions with the random effects of study.

The NRC-MPY model included DMI and dietary concentrations of $\mathrm{CP}$, metabolizable protein, $\mathrm{NDF}$, and

Figure 5. Weighted residuals (weighted observed-weighted predicted) vs. weighted predicted milk protein yield (MPY). Panel A: CPM (a computer program based on the Cornell Net Carbohydrate and Protein System principles) model, across all lactation stages (AC = all cows); panel B: NRC (2001) model, across all lactation stages $(\mathrm{AC})$

BW. Inclusion of DIM in the full model case only slightly improved the model fit as evident by the 19-point reduction in BIC (residual structure for the AC model is shown on Figure 5). Both models contained a number of significant interactions between dietary components and quadratic terms for DMI, metabolizable protein, and BW. The DIM model included separate coefficients for DMI, the interaction of DMI and BW, and the quadratics term for DMI. In both models, DMI significantly interacted with the random effects of the study.

\section{DISCUSSION}

The diets included in this study encompassed a large variety of feeds $(n=88)$, but the majority used ingredi- 
Table 2. Estimates, standard errors and significance for the fixed and random components of the final candidate models for DMI $(\mathrm{kg} / \mathrm{d} ; \mathrm{n}=761)$.

\begin{tabular}{|c|c|c|c|c|}
\hline Lactation stage & Parameter $^{1}$ & Estimate & $\mathrm{SE}$ & $\begin{array}{c}P>|t| \\
\text { or } P>|z|^{2}\end{array}$ \\
\hline & $\longrightarrow$ CPM Dairy ${ }^{3}$ & & & \\
\hline \multirow{8}{*}{$\begin{array}{l}\text { All cows } \\
\left(\mathrm{BIC}^{5}=3030.5\right) \\
\left(\mathrm{RMSE}^{6}=1.65\right)\end{array}$} & Intercept & -9.856 & 9.0312 & 0.2763 \\
\hline & $\mathrm{CP}$ & -0.373 & 0.0598 & $<0.0001$ \\
\hline & $\mathrm{NE}_{\mathrm{L}}$ & 56.478 & 10.2500 & $<0.0001$ \\
\hline & $\mathrm{MP}$ & 0.808 & 0.0971 & $<0.0001$ \\
\hline & MPBact & -5.499 & 1.3996 & 0.0001 \\
\hline & ProtB1 & 0.998 & 0.1429 & $<0.0001$ \\
\hline & $\mathrm{NE}_{\mathrm{L}} * \mathrm{NE}_{\mathrm{L}}$ & -16.656 & 2.9993 & $<0.0001$ \\
\hline & MPBact*MPBact & 0.346 & 0.1310 & 0.0086 \\
\hline \multirow[t]{2}{*}{ Model variance components } & Intercept & 1.002 & 1.0781 & 0.1764 \\
\hline & $\mathrm{MP}$ & 0.038 & 0.0114 & 0.0004 \\
\hline \multirow{7}{*}{$\begin{array}{l}\text { All cows }{ }^{4} \\
(\mathrm{BIC}=2500.7) \\
(\mathrm{RMSE}=1.67)\end{array}$} & Intercept & 102.000 & 2.1982 & $<0.0001$ \\
\hline & $\mathrm{NE}_{\mathrm{L}}$ & -52.888 & 1.4160 & $<0.0001$ \\
\hline & $\mathrm{MP}$ & 0.641 & 0.0454 & $<0.0001$ \\
\hline & RDP & 0.274 & 0.0303 & 0.0150 \\
\hline & FNDF & -0.160 & 0.0114 & $<0.0001$ \\
\hline & $\mathrm{ADF}$ & -0.355 & 0.0208 & $<0.0001$ \\
\hline & Fat & 1.594 & 0.0623 & $<0.0001$ \\
\hline \multirow[t]{2}{*}{ Model variance components } & Intercept & 0.785 & 0.1541 & $<0.0001$ \\
\hline & Fat & 0.024 & 0.0081 & 0.0015 \\
\hline
\end{tabular}

\footnotetext{
${ }^{1} \mathrm{CP}, \mathrm{RDP}$, and $\mathrm{ADF}$ are measured as a percentage of $\mathrm{DM} ; \mathrm{NE}_{\mathrm{L}}$ is measured in $\mathrm{Mcal} / \mathrm{kg}$ of $\mathrm{DM}$. MP $(\%$ of $\mathrm{DM})=$ metabolizable protein; MPBact $(\%$ of $\mathrm{DM})=$ metabolizable protein from bacterial protein; ProtB1 $(\%$ of DM) = protein fraction B1; DIM $1=$ DIM $\leq 100 \mathrm{~d}$; DIM $2=\mathrm{DIM}>100 \mathrm{~d}$; FNDF $(\%$ of DM $)=$ forage NDF; and Fat $(\%$ of $\mathrm{DM})=$ dietary fat.

${ }^{2}$ For random effects.

${ }^{3} \mathrm{CPM}$ Dairy is a computer program based on the Cornell Net Carbohydrate and Protein System principles.

${ }^{4}$ The reduced DIM models were identical to the all cow model and are not repeated here.

${ }^{5} \mathrm{BIC}=$ Bayesian Information Criterion

${ }^{6} \mathrm{RMSE}=$ Root mean square error after adjusting for the random effect of experiment.
}

ents, which were typical for North American dairy diets (Mowrey and Spain, 1999; Kellogg et al., 2001), i.e., corn silage, alfalfa silage and hay, processed corn grain, and soybean meal. Therefore, the results from this meta-analysis will be most applicable to Holstein cows fed alfalfa, corn, and soybean meal-based diets.

Regarding chemical composition, the diets represented a large variation in protein, energy, fiber, starch, and discounted TDN concentration. Diets with $\mathrm{CP}$ between 17.0 and $19.5 \%$ of $\mathrm{DM}$ represented $63 \%$ of the total, and those with an $\mathrm{NE}_{\mathrm{L}}$ concentration of 1.56 to $1.67 \mathrm{Mcal} / \mathrm{kg}$ of DM represented $69 \%$ of the total. Rumen-degradable protein and RUP concentrations of 10.9 to 13.7 and 5.0 to $6.5 \%$ of DM represented 66 and $60 \%$, respectively, of the total diets. Diets with $\mathrm{NDF}$ and forage NDF concentrations of 26.8 to 32.9 and 16.8 to $27.1 \%$ of DM were, respectively, 65 and $73 \%$ of the total, and diets with ADF concentration of 18.3 to $21.5 \%$ of DM were $52 \%$ of the total. Calculated discounted TDN concentration varied less among diets; $75 \%$ of the diets had discounted TDN concentration between 63.6 and $67.5 \%$. A similar variation in dietary $\mathrm{CP}, \mathrm{NDF}$, and $\mathrm{ADF}$ concentration from a com- paratively smaller data set was reported by Holter et al. (1997). Thus, composition of the diets is in line with practical feeding and should ensure that the results from this study are applicable to most diets fed to dairy cows in North America.

In this data set, extremely high $\mathrm{PE}$ were associated with comparatively low dietary CP concentrations and very high MY (Bach et al., 2000). Thus, high PE was more often found with diets in which corn silage rather than alfalfa silage was the main forage ingredient, CP concentration was low, and cows were producing higher MY. Not surprisingly, dairy efficiency ( $\mathrm{kg}$ of solids-corrected MY/kg of DMI) was negatively correlated with DMI and positively correlated to MY in Holstein cows (Britt et al., 2003). Satter et al. (2002) calculated that with diets in which low DM alfalfa silage is the only forage, $20.8 \%$ dietary $\mathrm{CP}$, as predicted by NRC (2001), was needed to meet the requirements of a high-producing, non-pregnant dairy cow; with diets in which the forage was alfalfa hay and corn silage (1:1), the requirements of the cow would be met at $15.8 \%$ CP. Wilkerson et al. (1997) reported proportionally greater urinary $\mathrm{N}$ losses and lower $\mathrm{PE}$ with 
Table 3. Estimates, standard errors, and significance for the fixed and random components of the final candidate models for milk yield $(\mathrm{kg} / \mathrm{d} ; \mathrm{n}=777)$.

\begin{tabular}{|c|c|c|c|c|}
\hline Lactation stage & Parameter $^{1}$ & Estimate & SE & $\begin{array}{c}P>|t| \\
\text { or } P>|z|^{2}\end{array}$ \\
\hline & CPM Dairy ${ }^{3}$ & & & \\
\hline \multirow{5}{*}{$\begin{array}{l}\text { All cows } \\
\left(\mathrm{BIC}^{4}=3913.2\right) \\
\left(\mathrm{RMSE}^{5}=2.46\right)\end{array}$} & Intercept & 9.254 & 1.6652 & $<0.0001$ \\
\hline & DMI & 0.909 & 0.0488 & $<0.0001$ \\
\hline & MP & 0.631 & 0.0939 & $<0.0001$ \\
\hline & MPBact & -1.236 & 0.1805 & $<0.0001$ \\
\hline & CHOB1 & 0.081 & 0.0170 & $<0.0001$ \\
\hline \multirow{3}{*}{ Model variance components } & Intercept & 2.928 & 2.6614 & 0.1356 \\
\hline & DMI & 0.016 & 0.0048 & 0.0005 \\
\hline & MP & 0.050 & 0.0245 & 0.0197 \\
\hline \multirow{6}{*}{$\begin{array}{l}\text { DIM model } \\
(\mathrm{BIC}=3773.2) \\
(\mathrm{RMSE}=2.19)\end{array}$} & Intercept & 10.739 & 1.5102 & $<0.0001$ \\
\hline & DMI (DIM 1) & 0.919 & 0.0443 & $<0.0001$ \\
\hline & DMI (DIM 2) & 0.754 & 0.0460 & $<0.0001$ \\
\hline & MP & 0.597 & 0.0856 & $<0.0001$ \\
\hline & MPBact & -1.171 & 0.1635 & $<0.0001$ \\
\hline & CHOB1 & 0.074 & 0.0153 & $<0.0001$ \\
\hline \multirow[t]{3}{*}{ Model variance components } & Intercept & 1.874 & 1.9644 & 0.1701 \\
\hline & DMI*DIM & 0.008 & 0.0036 & 0.0088 \\
\hline & MP & 0.071 & 0.0178 & $<0.0001$ \\
\hline \multirow{4}{*}{$\begin{array}{l}\text { All cows } \\
\quad(\mathrm{BIC}=3891.6) \\
(\mathrm{RMSE}=2.49)\end{array}$} & Intercept & 1.368 & 1.2353 & 0.2691 \\
\hline & DMI & 1.041 & 0.0444 & $<0.0001$ \\
\hline & MP & 0.530 & 0.0878 & $<0.0001$ \\
\hline & Fat & 0.591 & 0.0905 & $<0.0001$ \\
\hline \multirow{2}{*}{ Model variance components } & Intercept & 4.749 & 2.0007 & 0.0088 \\
\hline & DMI & 0.019 & 0.0042 & $<0.0001$ \\
\hline \multirow{5}{*}{$\begin{array}{l}\text { DIM model } \\
(\mathrm{BIC}=3760.9) \\
(\mathrm{RMSE}=2.23)\end{array}$} & Intercept & 3.250 & 1.1486 & 0.0051 \\
\hline & DMI (DIM 1) & 1.047 & 0.0413 & $<0.0001$ \\
\hline & DMI (DIM 2) & 0.889 & 0.0432 & $<0.0001$ \\
\hline & $\mathrm{MP}$ & 0.483 & 0.0798 & $<0.0001$ \\
\hline & Fat & 0.555 & 0.0831 & $<0.0001$ \\
\hline \multirow[t]{2}{*}{ Model variance components } & Intercept & 5.868 & 1.5606 & $<0.0001$ \\
\hline & $\mathrm{DMI} * \mathrm{DIM}$ & 0.012 & 0.0030 & $<0.0001$ \\
\hline
\end{tabular}

\footnotetext{
${ }^{1} \mathrm{DMI}$ is measured in $\mathrm{kg} / \mathrm{d}, \mathrm{MP}(\%$ of $\mathrm{DM})=$ metabolizable protein, MPBact $(\%$ of $\mathrm{DM})=$ metabolizable protein from bacterial protein, CHOB1 $(\%$ of DM $)=$ carbohydrate fraction B1, DIM $1=\mathrm{DIM} \leq 100 \mathrm{~d}$, DIM $2=\mathrm{DIM}>100 \mathrm{~d}$, and Fat $(\%$ of $\mathrm{DM})=$ dietary fat.

${ }^{2}$ For random effects.

${ }^{3} \mathrm{CPM}$ Dairy is a computer program based on the Cornell Net Carbohydrate and Protein System principles. ${ }^{4} \mathrm{BIC}=$ Bayesian Information Criterion.

${ }^{5} \mathrm{RMSE}=$ Root mean square error after adjusting for the random effect of experiment.
}

low-producing cows $(<20 \mathrm{~kg} / \mathrm{d})$ than with high-producing cows ( $>20 \mathrm{~kg} / \mathrm{d}$ milk): $37.9 \%$ vs. $34.6 \%$ and $22.0 \%$ vs. $29.7 \%$, respectively. It has to be noted, however, that the high-producing cows excreted a total of 143 $\mathrm{g} / \mathrm{d}$ per $1000 \mathrm{~kg} \mathrm{BW}$ more $\mathrm{N}$ than the low-producing cows. As a proportion of intake, the total excreta $\mathrm{N}$ between the two groups was not dramatically different: $72.6 \%$ vs. $68.9 \%$ for low- and high-producing cows, respectively.

Both CPM and NRC DMI models included energy and protein components. The CPM model contained a quadratic term for $\mathrm{NE}_{\mathrm{L}}$, indicating a non-linear response to this variable. The NRC model included negative terms for $\mathrm{NE}_{\mathrm{L}}$, forage $\mathrm{NDF}$, and $\mathrm{ADF}$. High fiber diets may physically limit intake through the so-called fill effect (Mertens, 1987), and the effect of high energy diets, or diets with high concentration of rumen-de- graded starch on DMI is likely related to biochemical control (Montgomery and Baumgardt, 1965; Faverdin and Bareille, 1999). Metabolizable protein and a component related to ruminal availability of protein (protein fraction $\mathrm{B} 1$, true protein, or RDP) were present in both DMI models. The CPM model indicated a negative coefficient for metabolizable protein from bacteria protein. In most feeding systems, microbial protein synthesis is assumed to be energy-dependent (NKJ Protein Group, 1985; Tamminga et al., 1994; NRC, 2001; GfE, 2001) and increased production of metabolizable protein from bacteria protein would indicate increased overall digestibility of dietary energy. Inclusion of DIM did not improve the DMI models, suggesting little influence in the response because of stage of lactation. As a significant random effect, metabolizable protein (CPM) and dietary fat (NRC) appear to be a source of 
Table 4. Estimates, standard errors, and significance for the fixed and random components of the final candidate models for milk protein yield $\left(\mathrm{kg} / \mathrm{d} ; \mathrm{n}_{\mathrm{CPM}}=757\right.$ and $\left.\mathrm{n}_{\mathrm{NRC}}=552^{1}\right)$.

\begin{tabular}{|c|c|c|c|c|}
\hline Lactation stage & Parameter $^{2}$ & Estimate & $\mathrm{SE}$ & $\begin{array}{l}P>|\mathrm{t}| \\
\text { or } P>|z|^{3}\end{array}$ \\
\hline & \multicolumn{2}{|c|}{ CPM Dairy ${ }^{4}$} & & \\
\hline \multirow{11}{*}{$\begin{array}{l}\text { All cows } \\
\left(\mathrm{BIC}^{5}=160.8\right) \\
\left(\mathrm{RMSE}^{6}=3.21\right)\end{array}$} & Intercept & 1.031 & 0.0980 & $<0.0001$ \\
\hline & DMI & 0.022 & 0.0044 & $<0.0001$ \\
\hline & SolProt & 0.088 & 0.0177 & $<0.0001$ \\
\hline & NSC & 0.036 & 0.0024 & $<0.0001$ \\
\hline & CHOB1 & -0.048 & 0.0026 & $<0.0001$ \\
\hline & CHOA & -0.049 & 0.0041 & $<0.0001$ \\
\hline & ProtA & -0.195 & 0.0258 & $<0.0001$ \\
\hline & ProtB1 & -0.132 & 0.0235 & $<0.0001$ \\
\hline & $\mathrm{DMI} *$ SolProt & -0.009 & 0.0005 & $<0.0001$ \\
\hline & DMI*ProtA & 0.013 & 0.0010 & $<0.0001$ \\
\hline & CHOB1*ProtB1 & 0.006 & 0.0005 & $<0.0001$ \\
\hline \multirow[t]{3}{*}{ Model variance components } & Intercept & 0.002 & 0.0013 & 0.0319 \\
\hline & DMI & 0.021 E-3 & 3.686 E-6 & $<0.0001$ \\
\hline & ProtA & $0.212 \mathrm{E}-3$ & $0.057 \mathrm{E}-3$ & 0.0001 \\
\hline \multirow{17}{*}{$\begin{array}{l}\text { DIM model } \\
(\mathrm{BIC}=178.1) \\
(\mathrm{RMSE}=3.08)\end{array}$} & Intercept (DIM 1) & 1.676 & 0.1348 & $<0.0001$ \\
\hline & Intercept (DIM 2) & 0.610 & 0.1398 & $<0.0001$ \\
\hline & DMI (DIM 1) & -0.003 & 0.0057 & 0.6011 \\
\hline & DMI (DIM 2) & 0.039 & 0.0070 & $<0.0001$ \\
\hline & SolProt & 0.086 & 0.0234 & 0.0003 \\
\hline & NSC (DIM 1) & 0.036 & 0.0024 & $<0.0001$ \\
\hline & NSC (DIM 2) & 0.032 & 0.0057 & $<0.0001$ \\
\hline & CHOB1 (DIM 1) & -0.049 & 0.0026 & $<0.0001$ \\
\hline & CHOB1 (DIM 2) & -0.044 & 0.0055 & $<0.0001$ \\
\hline & CHOA & -0.045 & 0.0044 & $<0.0001$ \\
\hline & ProtA (DIM 1) & -0.311 & 0.0352 & $<0.0001$ \\
\hline & ProtA (DIM 2) & -0.099 & 0.0409 & 0.0167 \\
\hline & ProtB1 & -0.123 & 0.0271 & $<0.0001$ \\
\hline & DMI*SolProt & -0.009 & 0.0011 & $<0.0001$ \\
\hline & DMI*ProtA (DIM 1) & 0.018 & 0.0017 & $<0.0001$ \\
\hline & DMI*ProtA (DIM 2) & 0.009 & 0.0021 & $<0.0001$ \\
\hline & CHOB1*ProtB1 & 0.006 & 0.0006 & $<0.0001$ \\
\hline \multirow[t]{3}{*}{ Model variance components } & Intercept & 0.094 E-3 & 0.0014 & 0.4735 \\
\hline & DMI*DIM & 0.022 E-3 & $3.855 \mathrm{E}-6$ & $<0.0001$ \\
\hline & ProtA & $0.235 \mathrm{E}-3$ & $0.059 \mathrm{E}-3$ & $\begin{array}{l}<0.0001 \\
\text { continued }\end{array}$ \\
\hline
\end{tabular}

variability in the DMI response across studies. The difference in BIC (530 points) indicated a better fit with the NRC than with the CPM models. Body weight is routinely a factor in models for predicting DMI in dairy cows (Yungblut et al., 1981; Kertz et al., 1991; Roseler et al., 1997a; NRC, 2001); however, its effects might have been mitigated in these data when the random effect of study was accounted for. Because researchers often strive to balance the BW of animals within their studies, the random effect of $\mathrm{BW}$ on the responses may tend to vary more across studies than within them. Therefore, BW may well be confounded with the random effect of study, and this particular data set may not be well suited for studying its effects. In fact, BW was typically nonsignificant in the estimated models.

The models derived for MY and MPY reflected the relationships existing among the dietary variables and production parameters in this analysis. Although a variety of factors were involved in predicting MY and
MPY in both nutritional programs, the major variable influencing production in this data set was DMI (largest $F$ statistic). The energy component in the MY models was either CHO fraction B1 (starch; CPM) or dietary fat (NRC). Similar to the DMI models, metabolizable protein was important in predicting MY in both datasets. In both the CPM and NRC data, the full model incorporating DIM improved model fits for MY. Dry matter intake (and metabolizable protein for the CPM model) was a significant random component, indicating DMI contribution to MY variability over the studies. Both CPM and NRC datasets provided similar fits for MY.

Milk protein yield models derived through the CPM dataset were dominated (largest $F$ statistic) by DMI, but a number of protein- and CHO-related dietary factors were significant in predicting MPY. In general, the MPY models were not very parsimonious and should be considered less reliable than the DMI or MY models. Dry matter intake, dietary NDF concentra- 
Table 4 (continued). Estimates, standard errors, and significance for the fixed and random components of the final candidate models for milk protein yield $\left(\mathrm{kg} / \mathrm{d} ; \mathrm{n}_{\mathrm{CPM}}=757\right.$ and $\left.\mathrm{n}_{\mathrm{NRC}}=552^{1}\right)$.

\begin{tabular}{|c|c|c|c|c|}
\hline Lactation stage & Parameter $^{2}$ & Estimate & $\mathrm{SE}$ & $\begin{array}{l}P>|\mathrm{t}| \\
\text { or } P>|\mathrm{z}|^{3}\end{array}$ \\
\hline & $\longrightarrow$ NRC 2 & - & & \\
\hline \multirow{14}{*}{$\begin{array}{l}\text { All cows } \\
(\text { BIC }=-168.2) \\
(\text { RMSE }=3.19)\end{array}$} & Intercept & -2.556 & 0.6126 & $<0.0001$ \\
\hline & DMI & -0.057 & 0.0287 & 0.0497 \\
\hline & $\mathrm{CP}$ & -0.273 & 0.0327 & $<0.0001$ \\
\hline & MP & 0.478 & 0.0615 & $<0.0001$ \\
\hline & NDF & -0.003 & 0.0007 & $<0.0001$ \\
\hline & BW & 0.012 & 0.0019 & $<0.0001$ \\
\hline & $\mathrm{DMI} * \mathrm{BW}$ & 0.0003 & 0.0001 & $<0.0001$ \\
\hline & $\mathrm{DMI} * \mathrm{DMI}$ & -0.003 & 0.0007 & 0.0003 \\
\hline & $\mathrm{CP} * \mathrm{MP}$ & -0.008 & 0.0024 & 0.0005 \\
\hline & $\mathrm{CP} * \mathrm{BW}$ & 0.0003 & 0.0001 & $<0.0001$ \\
\hline & $\mathrm{CP} * \mathrm{CP}$ & 0.004 & 0.0009 & $<0.0001$ \\
\hline & $\mathrm{MP} * \mathrm{BW}$ & -0.0006 & 0.0001 & $<0.0001$ \\
\hline & $\mathrm{MP} * \mathrm{MP}$ & 0.005 & 0.0022 & 0.0127 \\
\hline & $\mathrm{BW} * \mathrm{BW}$ & $-0.020 \mathrm{E}-3$ & $2.009 \mathrm{E}-6$ & $<0.0001$ \\
\hline \multirow[t]{2}{*}{ Model variance components } & Intercept & 0.002 & 0.0025 & 0.2195 \\
\hline & DMI & 0.017 E-3 & 5.308 E-6 & 0.0006 \\
\hline \multirow{18}{*}{$\begin{array}{l}\text { DIM model } \\
(\mathrm{BIC}=-148.8) \\
(\mathrm{RMSE}=3.10)\end{array}$} & Intercept (DIM 1) & -1.843 & 0.6527 & 0.0053 \\
\hline & Intercept (DIM 2) & -0.385 & 0.8890 & 0.6653 \\
\hline & DMI (DIM 1) & -0.014 & 0.0312 & 0.6659 \\
\hline & DMI (DIM 2) & -0.114 & 0.0612 & 0.0640 \\
\hline & $\mathrm{CP}$ & -0.285 & 0.0326 & $<0.0001$ \\
\hline & MP & 0.492 & 0.0608 & $<0.0001$ \\
\hline & NDF & -0.004 & 0.0007 & $<0.0001$ \\
\hline & BW & 0.008 & 0.0020 & $<0.0001$ \\
\hline & DMI*BW (DIM 1) & 0.0003 & 0.0001 & $<0.0001$ \\
\hline & $\mathrm{DMI} * \mathrm{BW}(\mathrm{DIM} 2)$ & 0.0002 & 0.0001 & $<0.0001$ \\
\hline & DMI*DMI (DIM 1) & -0.003 & 0.0008 & $<0.0001$ \\
\hline & DMI*DMI (DIM 2) & -0.0002 & 0.0014 & 0.8810 \\
\hline & $\mathrm{CP} * \mathrm{MP}$ & -0.008 & 0.0024 & 0.0016 \\
\hline & $\mathrm{CP} * \mathrm{BW}$ & 0.0004 & 0.0001 & $<0.0001$ \\
\hline & $\mathrm{CP} * \mathrm{CP}$ & 0.003 & 0.0009 & 0.0005 \\
\hline & $\mathrm{MP} * \mathrm{BW}$ & -0.0007 & 0.0001 & $<0.0001$ \\
\hline & $\mathrm{MP} * \mathrm{MP}$ & 0.005 & 0.0021 & 0.0203 \\
\hline & $\mathrm{BW} * \mathrm{BW}$ & -0.010 E-3 & $2.183 \mathrm{E}-6$ & $<0.0001$ \\
\hline \multirow{2}{*}{ Model variance components } & Intercept & 0.002 & 0.0022 & 0.1545 \\
\hline & $\mathrm{DMI} * \mathrm{DIM}$ & $0.016 \mathrm{E}-3$ & $4.628 \mathrm{E}-6$ & 0.0003 \\
\hline
\end{tabular}

\footnotetext{
${ }^{1} \mathrm{n}_{\mathrm{CPM}}=$ Sample number for data using CPM Dairy and $\mathrm{n}_{\mathrm{NRC}}=$ sample number for data using NRC (2001); BW was only available for 552 observations for $\mathrm{n}_{\mathrm{NRC}}$.

${ }^{2} \mathrm{DMI}$ is measured in $\mathrm{kg} / \mathrm{d}$ and NSC, CP, and NDF are measured as a percentage of DM. SolProt (\% of $\mathrm{DM})=$ soluble protein, $\mathrm{CHOB} 1(\%$ of $\mathrm{DM})=$ carbohydrate fraction $\mathrm{B} 1 ; \mathrm{CHOA}(\%$ of $\mathrm{DM})=$ carbohydrate fraction $\mathrm{A} ;$ ProtA $(\%$ of $\mathrm{DM})=$ protein fraction $\mathrm{A}$; ProtB1 $(\%$ of $\mathrm{DM})=$ protein fraction $\mathrm{B} 1 ; \mathrm{DIM} 1=\mathrm{DIM} \leq$ $100 \mathrm{~d}$; DIM 2 = DIM > $100 \mathrm{~d}$; MP $(\%$ of DM $)=$ metabolizable protein. $\mathrm{BW}$ is measured in $\mathrm{kg}$.

${ }^{3}$ For random effects.

${ }^{4} \mathrm{CPM}$ Dairy is a computer program based on the Cornell Net Carbohydrate and Protein System principles. ${ }^{5} \mathrm{BIC}=$ Bayesian Information Criterion.

${ }^{6} \mathrm{RMSE}=$ Root mean square error after adjusting for the random effect of experiment.
}

tion, and digestibility of dietary OM were important in predicting MPY in the models of Rook et al. (1992). Moloi (1998) found that diet-related variables, such as degradable intake protein, NDF, and NFC concentration of the diet, impacted MPY in dairy cows. In the Moloi (1998) study, however, no single variable was distinguished as having major influence on MPY. Smoler et al. (1998) found generally poor prediction of milk protein concentration when diet-related variables were used in the modeling process; models included both $\mathrm{CHO}$ and protein variables. Inclusion of stage of lactation in the CPM-MPY model did not improve the model fit. The NRC-MPY models also included metabolizable protein, signifying the importance of the postruminal protein supply in milk protein synthesis. Concentrations of CP and NDF had negative coefficients in the NRC-MPY model. Similar results for NDF were reported by Rook et al. (1992), and these may be indicative of the negative relationship found by Emery (1978) between dietary fiber and milk protein concentration. Increased CP concentration of the diet has resulted in decreased efficiency of utiliza- 
tion of dietary $\mathrm{N}$ for milk protein synthesis (Etter et al., 2003) and lowered milk protein content (Leonardi et al., 2003). As evident from the difference in BIC (329 and 327 points, $\mathrm{AC}$ and DIM models, respectively), the NRC models improved the prediction of MPY relative to the CPM models.

\section{CONCLUSIONS}

Attempts to estimate DMI and production parameters based on diet composition yielded models that included protein and CHO fractions. Dry matter intake was the dominant variable in MY and MPY models. A variety of energy- or protein-related parameters were also important in modeling MY and MPY. Incorporating stage of lactation in the models improved the fit for MY but had no significant effect for DMI and MPY models. Models derived using CPM Dairy or NRC (2001) diet composition data had similar prediction accuracy for MY, but the NRC-derived DMI and MPY models resulted in better fits than the corresponding CPM models.

\section{ACKNOWLEDGMENTS}

This study was partially supported by funds from the Idaho Agricultural Experiment Station. The authors thank K. A. Hristova, T. Hubert, R. Manzo, K. L. Grandeen, and J. K. Ropp for assistance with collection of the initial data used in this study.

\section{REFERENCES}

Alderman, G., J. France, and E. Kebreab. 2001. A critique of the Cornell Net Carbohydrate and Protein System with emphasis on dairy cattle. 1. The rumen model. J. Anim. Feed Sci. 10:1-24.

Bach, A., G. B. Huntington, S. Calsamiglia, and M. D. Stern. 2000. Nitrogen metabolism of early lactation cows fed diets with two different levels of protein and different amino acid profiles. J. Dairy Sci. 83:2585-2595.

Bateman, H. G., J. H. Clark, R. A. Patton, C. J. Peel, and C. G. Schwab. 2001. Accuracy and precision of computer models to predict passage of crude protein and amino acids to the duodenum of lactating dairy cows. J. Dairy Sci. 84:649-664.

Blaxter, K. L., F. W. Wainman, and J. L. Davidson. 1966. The voluntary intake of food by sheep and cattle in relation to their energy requirements for maintenance. Anim. Prod. 8:75-83.

Britt, J. S., R. C. Thomas, N. C. Speer, and M. B. Hall. 2003. Efficiency of converting dry matter to milk in Holstein herds. J. Dairy Sci. 86:3796-3801.

Emery, R. S. 1978. Feeding for increased milk protein. J. Dairy Sci. 61:825-828.

Etter, R. P., A. N. Hristov, J. K. Ropp, and K. L. Grandeen. 2003. Effect of dietary crude protein level and degradability on ruminal fermentation and nitrogen utilization in lactating dairy cows. J. Dairy Sci. 86(Suppl. 1):59.

Faverdin, P., and N. Bareille. 1999. Lipostatic regulation of feed intake in ruminants. Pages 89-102 in Regulation of Feed Intake. D. van der Heide, E. A. Huisman, E. Kanis, J. W. M. Osse, and M. W. A. Verstegen, ed. CAB International Publishing, Wallingford, UK.
Firkins, J. L., M. L. Eastridge, N. R. St-Pierre, and S. M. Noftsger. 2001. Effects of grain variability and processing on starch utilization by lactating dairy cattle. J. Anim. Sci. 79(E. Suppl.):E218-E238.

Fuentes-Pila, J., M. A. DeLorenzo, D. K. Beede, C. R. Staples, and J. B. Holter. 1996. Evaluation of equations based on animal factors to predict intake of lactating Holstein cows. J. Dairy Sci. 79:1562-1571.

GfE (Ausschuss für Bedarfsnormen der Gesellschaft für Ernährungsphysiologie). 2001. Empfehlungen zur Energie- und Nährstoffversorgung der Milchkühe und Aufzuchtrinder. Energie- und Nährstoffbedarf landwirtschaftlicher Nutztiere. No. 8. DLGVerlag, Frankfurt am Main, Germany.

Haig, P. A., T. Mutsvangwa, R. Spratt, and B. W. McBride. 2002. Effects of dietary protein solubility on nitrogen losses from lactating dairy cows and comparison with predictions from the Cornell Net Carbohydrate and Protein System. J. Dairy Sci. 85:1208-1217.

Harlan, D. W., J. B. Holter, and H. H. Hayes. 1991. Detergent fiber traits to predict productive energy of forages fed free choice to nonlactating dairy cattle. J. Dairy Sci. 74:1337-1353.

Holter, J. B., J. W. West, M. L. McGilliard, and A. N. Pell. 1996. Predicting ad libitum dry matter intake and yields of Jersey cows. J. Dairy Sci. 79:912-921.

Holter, J. B., J. W. West, and M. L. McGilliard. 1997. Predicting ad libitum dry matter intake and yield of Holstein cows. J. Dairy Sci. 80:2188-2199.

Hristov, A. N., K. A. Hristova, and W. J. Price. 2000. Relationship between dry matter intake, body weight, and milk yield in dairy cows: A summary of published data. J. Dairy Sci. 83(Suppl. 1):260.

Jarrige, R. 1989. Ruminant Nutrition. Recommended Allowances and Feed Tables. Institut National de la Recherche Agronomique, Libbey, Eurotext, Paris, France.

Kellogg, D. W., J. A. Pennington, Z. B. Johnson, and R. Panivivat. 2001. Survey of management practices used for the highest producing DHI herds in the United States. J. Dairy Sci. 84(E. Suppl.):E120-E127.

Kertz, A. F., L. F. Reutzel, and G. M. Thomson. 1991. Dry matter intake from parturition to midlactation. J. Dairy Sci. 74:2290-2295.

Kohn, R. A., K. F. Kalscheur, and M. Hanigan. 1998. Evaluation of models for balancing the protein requirements for dairy cattle. J. Dairy Sci. 81:3402-3414.

Leonardi, C., M. Stevenson, and L. E. Armentano. 2003. Effect of two levels of crude protein and methionine supplementation on performance of dairy cows. J. Dairy Sci. 86:4033-4042.

Martin, O., and D. Sauvant. 2002. Meta-analysis of input/output kinetics in lactating dairy cows. J. Dairy Sci. 85:3363-3381.

Mertens, D. R. 1987. Predicting intake and digestibility using mathematical models of ruminal function. J. Anim. Sci. 64:1548-1558.

Mertens, D. R. 1997. Creating a system for meeting the fiber requirements of dairy cows. J. Dairy Sci. 80:1463-1481.

Moloi, I. P. 1998. Meta-analysis of nutritional factors that affect milk protein yield. M. S. Thesis. University of Idaho, Moscow.

Montgomery, M. J., and B. R. Baumgardt. 1965. Regulation of food intake in ruminants. 1. Pelleted rations varying in energy concentration. J. Dairy Sci. 48:569-574.

Moore, T. L., and I. L. Mao. 1990. Prediction of total intake of dry matter and net energy in a lactation. J. Dairy Sci. 73:1255-1262.

Moscardini, S., T. C. Wright, P. H. Luimes, B. W. McBride, and P. Susmel. 1998. Effects of rumen-undegradable protein and feed intake on purine derivative and urea nitrogen: Comparison with predictions from the Cornell Net Carbohydrate and Protein System. J. Dairy Sci. 81:2421-2429.

Mowrey, A., and J. N. Spain. 1999. Results of a nationwide survey to determine feedstuffs fed to lactating dairy cows. J. Dairy Sci. 82:445-451.

NKJ Protein Group. 1985. Introduction of the Nordic protein evaluation system for ruminants into practice and future research requirements. Proposals by the NKJ protein group. Acta Agric. Scand. 25(Suppl.):216-220. 
NRC. 1989. Nutrient Requirements of Dairy Cattle. 6th rev. ed. National Academy Press, Washington, DC.

NRC. 2001. Nutrient Requirements of Dairy Cattle. 7th rev. ed. National Academy Press, Washington, DC.

Oldick, B. S., J. L. Firkins, and N. R. St-Pierre. 1999. Estimation of microbial nitrogen flow to the duodenum of cattle based on dry matter intake and diet composition. J. Dairy Sci. 82:1497-1511.

Pittroff, W., and M. M. Kothmann. 2001. Quantitative prediction of feed intake in ruminants II. Conceptual and mathematical analysis of models for cattle. Livest. Prod. Sci. 71:151-169.

Rayburn, E. B., and D. G. Fox. 1993. Variation in neutral detergent fiber intake of Holstein cows. J. Dairy Sci. 76:544-554.

Rook, A. J., J. D. Sutton, and J. France. 1992. Prediction of the yield of milk constituents in dairy cows offered silage ad libitum and concentrate at a flat rate. Anim. Prod. 54:313-322.

Roseler, D. K., D. G. Fox, L. E. Chase, A. N. Pell, and W. C. Stone. 1997a. Development and evaluation of equations for the prediction of feed intake for lactating Holstein dairy cows. J. Dairy Sci. 80:878-893.

Roseler, D. K., D. G. Fox, A. N. Pell, and L. E. Chase. 1997b. Evaluation of alternative equations for prediction of intake for Holstein dairy cows. J. Dairy Sci. 80:864-877.

Santos, F. A. P., J. E. P. Santos, C. B. Theurer, and J. T. Huber. 1998. Effects of rumen-undegradable protein on dairy cow performance: A 12-year literature review. J. Dairy Sci. 81:31823213.
Satter, L. D., T. J. Klopfenstein, and G. E. Erickson. 2002. The role of nutrition in reducing nutrient output from ruminants. J. Anim. Sci. 80(E. Suppl. 2):E143-E156.

SAS/STAT. User's Guide, Version 8. 1999. SAS Inst., Inc., Cary, NC.

Smoler, E., A. J. Rook, J. D. Sutton, and D. E. Beever. 1998. Prediction of milk protein concentration from elements of the metabolism protein system. J. Dairy Sci. 81:1619-1623.

Sniffen, C. J., J. D. O'Connor, P. J. Van Soest, D. G. Fox, and J. B. Russell. 1992. A net carbohydrate and protein system for evaluating cattle diets: II. Carbohydrate and protein availability. J. Anim. Sci. 70:3562-3577.

St-Pierre, N. R. 2001. Integrating quantitative findings from multiple studies using mixed model methodology. J. Dairy Sci. 84:741-755.

St-Pierre, N. R. 2003. Reassessment of biases in predicted nitrogen flows to the duodenum by NRC 2001. J. Dairy Sci. 86:344-350.

Tamminga, S., W. M. van Straalen, A. P. J. Subnel, R. G. M. Meijer, A. Steg, C. J. G. Wever, and M. C. Blok. 1994. The Dutch protein evaluation system: The DVE/OEB system. Livest. Prod. Sci. 40:139-155.

Wilkerson, V. A., D. R. Mertens, and D. P. Casper. 1997. Prediction of excretion of manure and nitrogen by Holstein dairy cows. J. Dairy Sci. 80:3193-3204.

Yungblut, D. H., J. B. Stone, G. K. MacLeod, D. G. Grieve, and E. B. Burnside. 1981. The development of feed intake prediction equations for lactating dairy cows. Can. J. Anim. Sci. 61:151157. 